\title{
EFFECT OF FIRE RETARDANT ON FIRE PERFORMANCE OF PARTICLEBOARDS PRODUCED FROM AGRICULTURAL WASTES
}

\author{
Hend, A. M. El-Maghawry*
}

\begin{abstract}
The feasibility of applying flame retardants usually used to improve fire behavior of pressed wood was evaluated in the present study for the production of fire-retardant particleboard panels. Corn stalks and Peanut shells as a raw material were used for producing particleboards. Boric acid as a fire retardant was mixed with the used raw materials for producing fire retardant particleboards. Experiments were conducted to study some different operating parameters (particleboard thickness and fire retardant percentage) affecting the fire retardant particleboard production. The produced particleboard samples were evaluated in terms of time to ignition, charring depth, char index and charring rate. The experimental results revealed that time to ignition (245 and $220 \mathrm{~min}$ ), charring depth (2.68 and $3.80 \mathrm{~mm}$ ), char index (7.56 and $10.11 \%$ ) and charring rate (0.66 and 1.04 $\mathrm{mm} / \mathrm{h}$ ) of the produced fire retardant particleboards from corn stalks and Peanut shells, respectively. These results were in the case of using $16 \%$ fire retardant percentage with acceptable particleboard thickness of $22 \mathrm{~mm}$.
\end{abstract}

\section{INTRODUCTION}

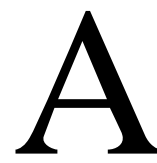
gricultural wastes can be used to produce particleboards (PB), medium density fiberboards (MDF), or high-density fiberboards (HDF) with acceptable physical, mechanical and fire resistant properties in an environmentally technology. Particleboard is a granular panel product composite of various sizes cellulose particles, which are bonded with synthetic resin under conditions of pressure and heat. To produce products suitable for specific final uses, resin levels, board density, particle engineering and manufacturing processes may be developed. Particleboard is distinguished from traditional wood as being cheaper, more dense and regular. Particleboards have many uses at present as they involve the installation of buildings, furniture, and cabinets.

\footnotetext{
*Lecturer of Agric. Eng., Fac. of Agric., Zagazig Univ.
} 
As one of the main determinants of the use of particleboards in institutional and industrial applications is their flammability. Additions can be combined at the time of manufacture to convey improvements in specific performance including greater dimensional stability as well as increased fire resistance and humidity. The concept of fire resistance is defined as the period during which the building element resists the passage of flame, and is still free from collapse and insulation against the excessive temperature of the non-exposed face.

To increase resistance to fire, particleboards are treated with fire retardant chemicals. Effectiveness of diverse fire retardant treatments on wood particleboards has been scrutinized by many studies. Karastergiou and Philippou (2000) investigated the thermogravimetric analysis of particleboards treated with various fire retardants. The analysis showed that fire retardants changed the particleboards thermal decomposition reaction. Basson and Conradie (2001) found that fire resistant use for particleboards consists of a solution containing urea, phosphoric acid, and ethanol resulting in excellent fire retardation. Rowell and LeVanGreen (2005) stated that boric acid is an inorganic fire retardant that increases the dehydration reaction in the cellulose component of wood. This reaction leads to increase amounts of char, reduce amounts of volatile organic compound and reduce smoldering and glowing combustion. Therefore, in particleboard manufacturing, it is assumed that boric acid can be used as a flame retardant without any adverse effect on urea formaldehyde adhesive. Harada et al. (2006) conducted fire resistance tests for thick plywood, particleboard, and medium density fiberboard with sample thicknesses of about $28-30 \mathrm{~mm}$, and assessed their suitability for fire protection structures. Results showed that for the initial heat release rate and time to ignition, the surface layer density of the plywood, particleboard and medium density fiberboard was the dominant parameter. Mouritz and Gibson (2006) mentioned that the most important properties of flammable material are time to ignition, heat release rate, extinction flammability index and thermal stability index, surface spread of flame, smoke toxicity, fire resistance, mass loss and limiting oxygen index. Ayrilmis et al. (2007) examined the physical, mechanical and fire resistant properties of oriented strand board with fire 
retardant treated veneers. They found that the effective fire retardant treatment was limewater, where it delayed the times for sustained ignition and reduced both the mass loss rate and the effective heat of combustion. National Building Code of Canada (2010) defined fire retardant treated wood as the wood that has been treated with fireretardant chemicals in solution under high pressure. It was observed that surface burning characteristics including rate of fuel contribution, flame spread and smoke contribution were reduced by the treatment. Pedieu $\boldsymbol{e t}$ al. (2012) determined wood particleboards fire retardant performance treated during wood particles blending with adhesive and different percentages of boric acid $(8,12$, and $16 \%)$. They found that the best fire retardant properties including weight loss, flames spread speed and after flame time were shown for particleboards treated with $16 \%$ boric acid resulting in case of decreasing the flame spread speed and enhancing the internal bond and thickness swelling of the manufactured particleboards.

Canadian Wood Council (2014) reported that fire retardant treated wood products are harder to ignite than untreated wood products. Fire retardant treatment enhances products fire performance by reducing heat release amount during the first fire stages, delays flame spread and limits smoke production from wood during fire. The treatments also reduced the amount of flammable volatiles released during fire exposure. Khozeini et al. (2014) investigated fire resistance and mechanical properties of wood flour-polypropylene composites with applying different amounts of ammonium polyphosphate (0,2 and $4 \%)$. Results proved that mechanical properties including fire resistance, tensile and flexural strengths of composites were enhanced by adding fire retardant. However, fire retardant increasing led to a decrease in impact strength.

Okai et al. (2015) determined the potential of utilizing agricultural residues such as corn stalk, elephant grass and sugar cane bagasse as an alternative timber species for particleboard manufacturing with the aim of reducing pressure on tropical forests. Results indicated that the corn stalk and elephant grass particleboards are denser than some mediumdensity particleboards produced from timber species. Reham (2017) investigated the effect of pressing temperature and resin ratio on some physical and mechanical properties of pressed wood produced from 
different recycled farm crop residues. Results showed that greater mechanical and physical properties were obtained in the case of using pressing temperature of $180{ }^{\circ} \mathrm{C}$ with $8 \%$ resin percentage.

The use of wood is always associated with regulations and safety requirements concerning their ignition and fire release properties, therefore the exact choice of type and proportion of fireproof material used during particleboard manufacture could overcome these limitations. Referring to the above mentioned literature review, the objective of the present study was to explore the possibility of applying flame retardant as a fireproofing agent which is usually used to improve behavior of wood against fire for the production of fire retardant particleboards from agricultural wastes.

\section{MATERIALS AND METHODS}

The main experiments were carried out through the year of 2017 at a private workshop in Zagazig city, Sharkia Governorate, Egypt to produce high quality fire retardant particleboards using agricultural wastes.

\section{Materials:}

\subsection{The agricultural wastes}

Corn stalks and Peanut shells were obtained for this study as agricultural wastes in order to produce fire retardant particleboards. Corn stalks and Peanut shells chemical compositions were listed in Table 1.

Agricultural wastes were cleaned from dust and dirt, coarsely chopped then, screened using a horizontal screen shaker. During particleboard production, particles were dried in an oven at $100-110{ }^{\circ} \mathrm{C}$ to reach $3 \%$ moisture content.

Table (1): Chemical compositions of corn stalks and peanut shells, \%

\begin{tabular}{|c|c|c|c|c|c|c|c|}
\hline \multirow{2}{*}{$\begin{array}{c}\text { Agricultural } \\
\text { waste }\end{array}$} & Cellulose & $\begin{array}{c}\text { Hemi- } \\
\text { Cellulose }\end{array}$ & Lignin & $\begin{array}{c}\text { Alcohol- } \\
\text { benzene }\end{array}$ & $\begin{array}{c}1 \% \\
\mathrm{NaOH}\end{array}$ & $\begin{array}{c}\text { Hot } \\
\text { water }\end{array}$ & $\begin{array}{c}\text { Cold } \\
\text { water }\end{array}$ \\
\hline Corn stalks & 36.4 & 39.7 & 13.8 & 4.21 & 53.40 & 16.98 & 20.42 \\
\hline Peanut shells & 39.2 & 17.5 & 28.3 & 6.82 & 34.65 & 11.93 & 16.78 \\
\hline
\end{tabular}




\subsection{Additives}

A urea formaldehyde resin with a solid content of $55 \%$ and a ratio of 10 $\%$ based on the agricultural wastes oven dry weight was used for producing particleboards.

Agricultural wastes were treated with boric acid which used as a fire retardant agent prior to use in fire retardant particleboards manufacture. To control ignition, flame spread and to lower heat release rate from the wooden surface substrate, boric acid was applied in fire retardant particleboards manufacture. Boric acid was added to the urea formaldehyde at final percentages. The glue was catalyzed by adding ammonium chloride as hardener (solid content 33\%) at $1 \%$ (based on glue weight).

\subsection{Manufacturing of fire retardant particleboard}

The used agricultural wastes were adhered by mixing them with additives (Resin, hardener and fire retardant) which sprayed for five minutes to obtain a homogenized mixture and to thoroughly impregnate the boric acid into the wastes in a vertical mixer before pressing particleboard panels. After mixing, samples were formed in a mold prior to hot pressing. Particleboards samples were conditioned prior to testing at a temperature of $20^{\circ} \mathrm{C}$ and $65 \%$ relative humidity for four weeks to obtain equilibrium moisture content. The process flow diagram of fire retardant particleboard manufacturing was presented in Fig. 1.

\section{Methods:}

Experiments were accomplished to investigate the fire-retardant properties of particleboards manufactured with added boric acid as a fireproofing agent using agricultural wastes for producing high quality fire retardant particleboards.

\subsection{Experimental conditions:}

The characteristics of the produced fire retardant particleboards were experimentally investigated under the following parameters:

- Two different agricultural wastes (Corn stalks and Peanut shells).

- Four different particleboard thicknesses (10, 14, 18 and $22 \mathrm{~mm}$ ).

- Four different percentages of fire retardant (4, 8, 12 and 16\%) based on oven-dry weight of agricultural wastes. 


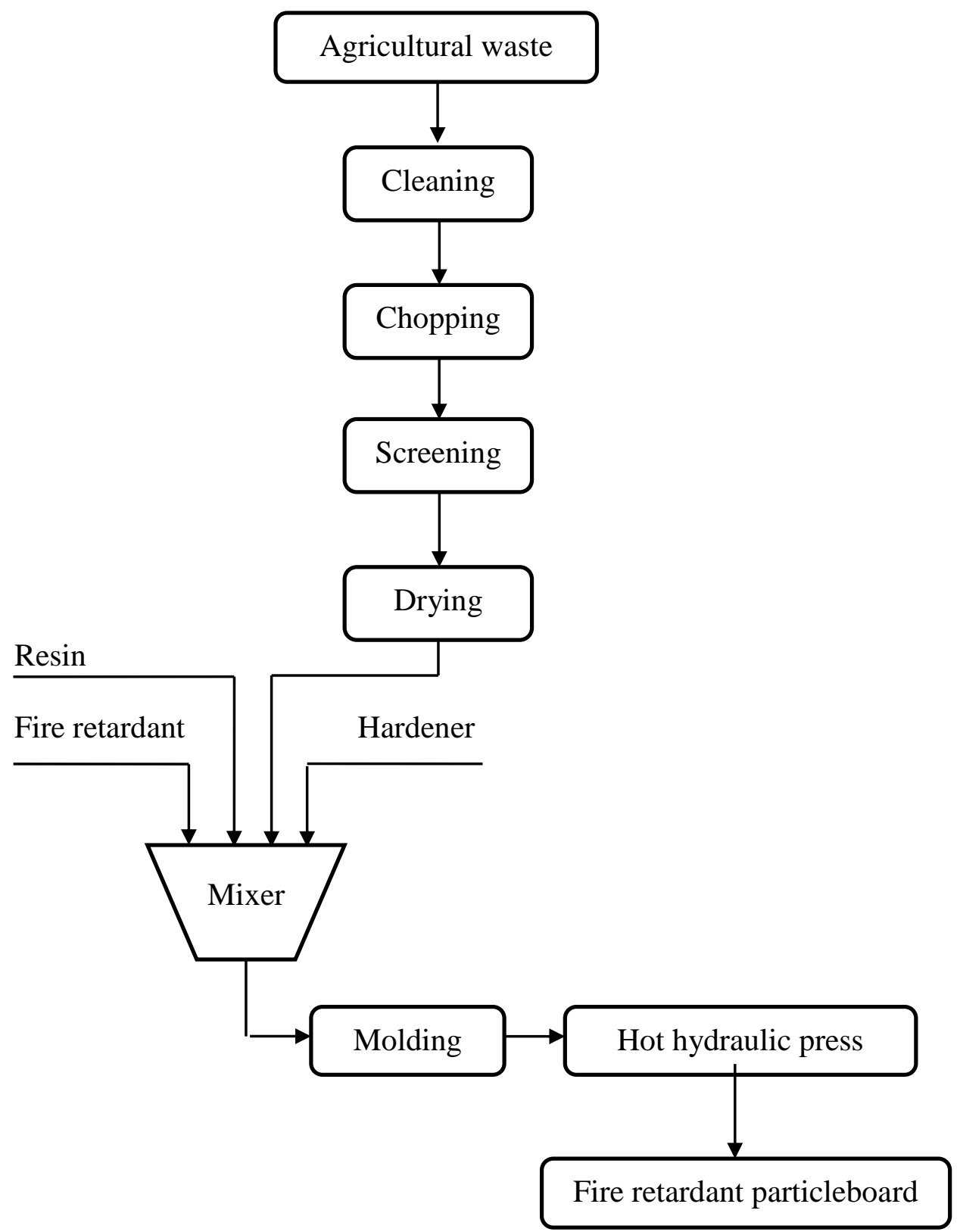

Fig. (1): Flow diagram of fire retardant particleboards manufacturing process.

\subsection{Experimental procedure:}

Experiments were carried out for producing particleboard samples with dimensions of $250 \times 300 \mathrm{~mm}$ with the previous mentioned 
thicknesses. The produced particleboards were manufactured under constant pressure of $2.4-2.6 \mathrm{~N} / \mathrm{mm}^{2}$, pressing temperature of $150{ }^{\circ} \mathrm{C}$ and pressing time of $7 \mathrm{~min}$, as recommended by (Güler et al. 2016;

\section{Güler and Büyüksarı 2011).}

Whereas the previous conditions of pressure, pressing temperature, pressing time and resin ratio produced particleboard samples with acceptable values of both mechanical properties (modulus of elasticity and modulus of rupture) and physical properties (thickness swelling and water absorption).

\subsection{Measurements and determinations:}

Particleboard samples were clamped with steel holders. One surface of the experimented particleboard sample is exposed vertically to a direct flame of length $37 \mathrm{~mm}$ from an opening of $8 \mathrm{~mm}$ diameter using an alcohol burner.

The manufactured fire retardant particleboard samples were evaluated taking into consideration time to ignition, charring depth, char index, and charring rate.

\subsubsection{Time to ignition $\left(T_{i}\right)$}

Fire retardant properties were measured in terms of time to ignition for the different particleboard sample thicknesses. The fire endurance time of the produced particleboards were measured by recording the times for the tested samples to be charred and ignited.

\subsubsection{Charring depth $\left(d_{\text {char }}\right)$}

The damage by fire is measured in terms of charring depth for the different particleboard sample thicknesses. Flame penetration through the particleboard was determined in terms of char depth.

\subsubsection{Char index (INC)}

The panels are cut with circular saw along the lines of maximum length and width of attack, measure the maximum width of charring of the wood panel on the lateral cut. Similarly, the charring maximum length found on the longitudinal cut and the maximum depth to which charring has penetrated the wood were measured. The thickness after burning and both the maximum width and length of carbonization are measured.

Char Index (INC \%) can be obtained according to the following formula (Garay, 2012). 


$$
\operatorname{INC}(\%)=\left(\frac{l_{M A X} * a_{M A X} * e_{C}}{V_{\text {INICIAL }}}\right) * 100
$$

Where: $l_{\text {Max }}$ - maximum length of carbonization, $\mathrm{mm}$;

$a_{\text {Max }}$ - maximum width of carbonization, $\mathrm{mm}$;

$e_{C}$ - burned thickness (difference between thickness prior and after the test), mm;

$V_{\text {INICIAL }}$ - Volume of the specimen prior to the test, $\mathrm{mm}^{3}$.

\subsubsection{Charring rate $(\beta)$}

The following formula was used to estimate the wood charring rate (Mikkola, 1991):

$$
\beta(\mathrm{mm} / \mathrm{h})=\frac{\mathrm{d}_{\text {char }}(\mathrm{mm})}{\mathrm{T}_{\mathrm{i}}(\mathrm{h})}
$$

Where: $\beta$ - charring rate, $\mathrm{mm} / \mathrm{h}$;

$\mathrm{d}_{\text {char }}$ - charring depth, mm;

$\mathrm{T}_{\mathrm{i}} \quad$ - time to ignition, $\mathrm{h}$.

\section{RESULTS AND DISCUSSION}

The discussion will cover the obtained results under the following heads:

\section{Effect of some variables on time to ignition and charring depth of the produced particleboards}

\subsection{Time to ignition}

The effect of both particleboard thickness and fire retardant percentage on the time to ignition was shown in Fig. 2. Considering the effect of particleboard thickness on the time to ignition, results showed the nonlinear relationship between time to ignition and particleboard thickness. It was clear that the increase of particleboard thickness from 10 to $22 \mathrm{~mm}$, the time to ignition is followed with an increase from 38 to 157, from 50 to 200 , from 65 to 218 , and from 73 to $245 \mathrm{~min}$ for corn stalks and from 32 to 130 , from 38 to 158 , from 47 to 188 , and from 55 to $220 \mathrm{~min}$ for peanut shells under fire retardant percentages of $4,8,12$ and $16 \%$, respectively. This is in agreement with Hume (1992) who stated that the time to ignition increases with the increase of the testing material thickness. Increasing time to ignition by increasing particleboard thickness for both corn stalks and peanut shells is attributed to that 
thicker wood particleboard get a thicker protective char layer which means slower fire penetration and higher fire resistance resulting in remarkable increase in time to ignition. Time to ignition values of corn stalks are higher than peanut shells because of the different chemical compositions of both of them.
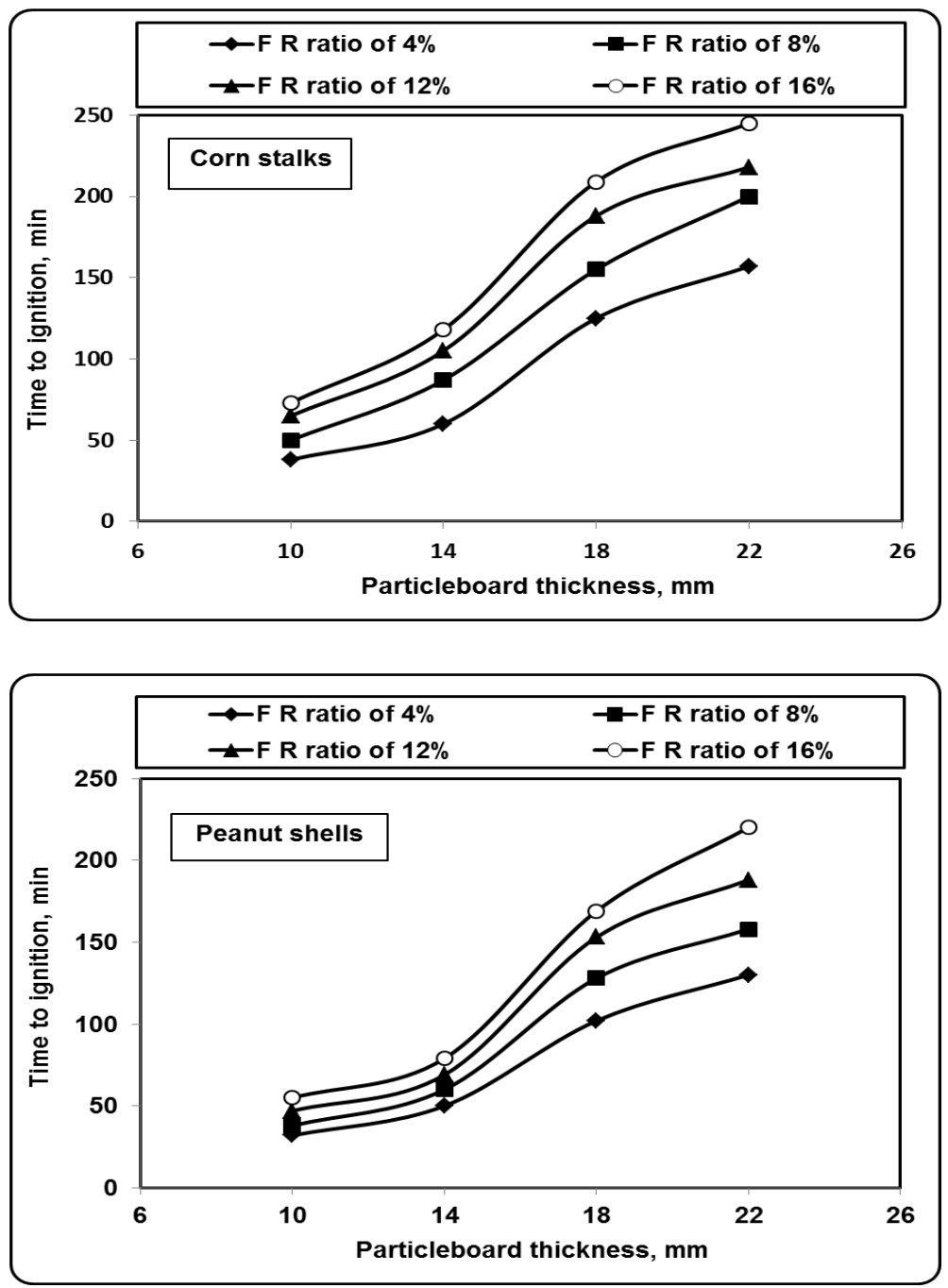

Fig. (2): Effect of sample thickness and fire retardant percentage on time to ignition under different kinds of agricultural wastes

Relating to the effect of fire retardant percentage on the time to ignition, obtained results in Fig. 2 show that increasing fire retardant percentage from 4 to $16 \%$, increased the time to ignition from 38 to 73 , from 60 to 
118, from 125 to 209 , and from 157 to 245 min for corn stalks and from 32 to 55 , from 50 to 79 , from 102 to 169 , and from 130 to $220 \mathrm{~min}$ for peanut shells at particleboard thicknesses of 10, 14, 18 and $22 \mathrm{~mm}$, respectively.

The reason in increasing the time to ignition by increasing fire retardant percentage is due to the increase of fire retardant proportion which leads to an increase in fire endurance time of the produced fire retardant particleboards.

\subsection{Charring depth}

The effect of particleboard thickness on charring depth is illustrated in Fig. 3. It is noticed that increasing particleboard thickness from 10 to 22 $\mathrm{mm}$ is accompanied with an increase in charring depth from 1.25 to 2.2, from 1.52 to 2.38 , from 1.8 to 2.52 and from 1.95 to $2.68 \mathrm{~mm}$ for corn stalks and from 2.05 to 3.25 , from 2.26 to 3.5 , from 2.42 to 3.68 , and from 2.6 to $3.8 \mathrm{~mm}$ for peanut shells at fire retardant percentages of 4,8 , 12 and $16 \%$.

Relating to the effect of fire retardant percentage on charring depth, obtained results in Fig. 3 show that increasing fire retardant percentage from 4 to $16 \%$, the charring depth is followed with an increase from 1.25 to 1.95 , from 1.3 to 1.99 , from 1.8 to 2.4 and from 2.2 to $3.68 \mathrm{~mm}$ for corn stalks and from 2.05 to 2.6 , from 2.1 to 2.62 , from 2.6 to 3.19 , and from 3.25 to $3.8 \mathrm{~mm}$ for peanut shells under particleboard thicknesses of 10, 14,18 and $22 \mathrm{~mm}$.

Increasing charring depth by increasing fire retardant percentage for both corn stalks and peanut shells is attributed to that fire retardant materials start interaction when temperatures reach the point below the point at which the wood will ignite then non-flammable gases and water vapor are formed and emitted at a steady slow rate, thus isolating the particleboard panel from the temperatures that will cause it to burn resulting in increasing charring depth without reaching the ignition point.

\section{Effect of some variables on char index and charring rate of the produced particleboard}

\subsection{Char index}

Representative values of char index versus particleboard thickness are given through various fire retardant percentages in Fig. 4. The obtained 
results show that with the increase of particleboard thickness from 10 to $22 \mathrm{~mm}$, the char index increased from 1.19 to 4.18 , from 2.48 to 5.3, from 3.95 to 6.29 and from 4.72 to $7.56 \%$ for corn stalks and from 2.48 to 6.33 , from 3.49 to 7.9 , from 4.23 to 9.18 and from 4.98 to $10.11 \%$ for peanut shells at fire retardant percentages of $4,8,12$ and $16 \%$, respectively.
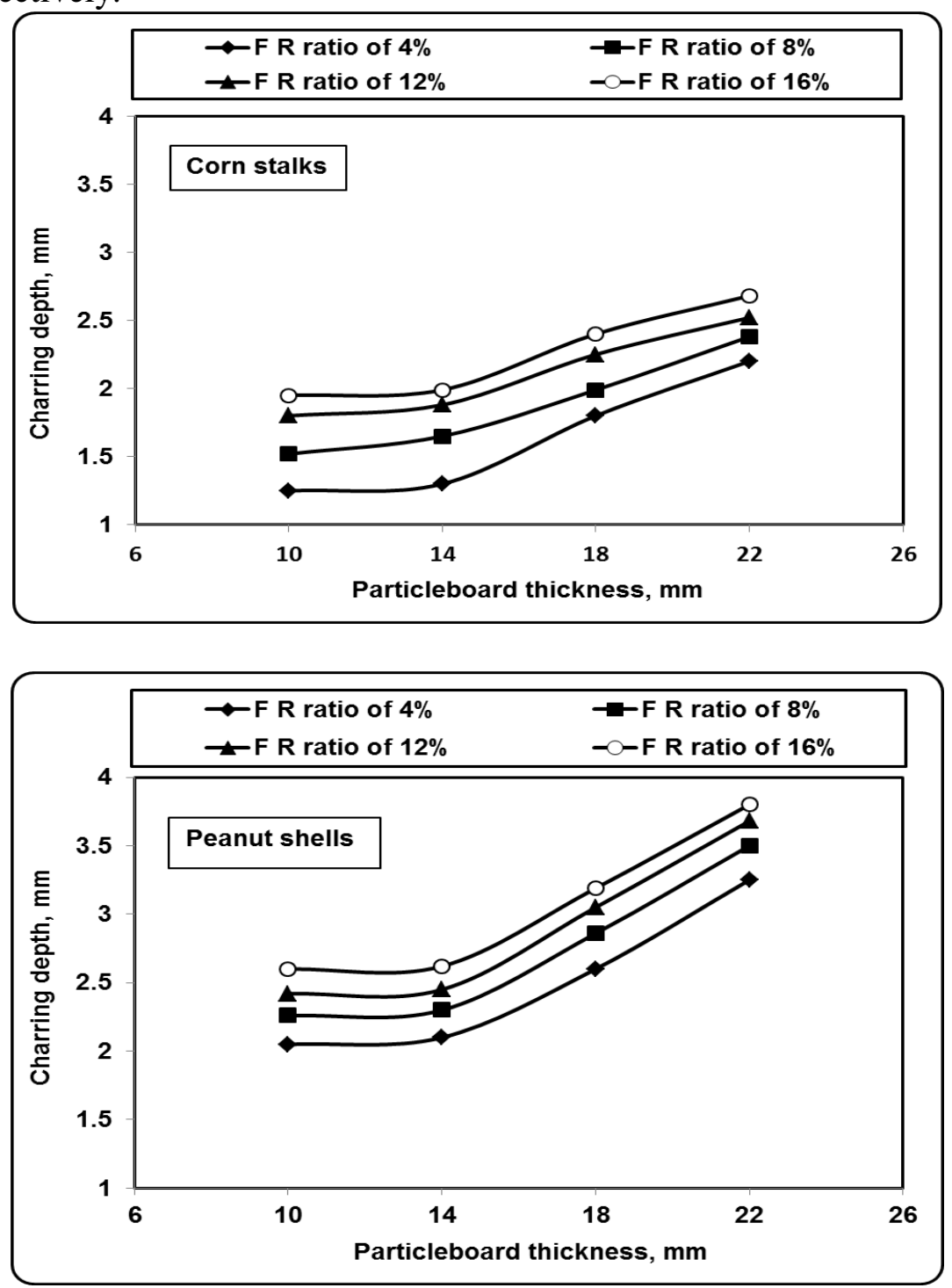

Fig. (3): Effect of sample thickness and fire retardant percentage on charring depth under different kinds of agricultural wastes 

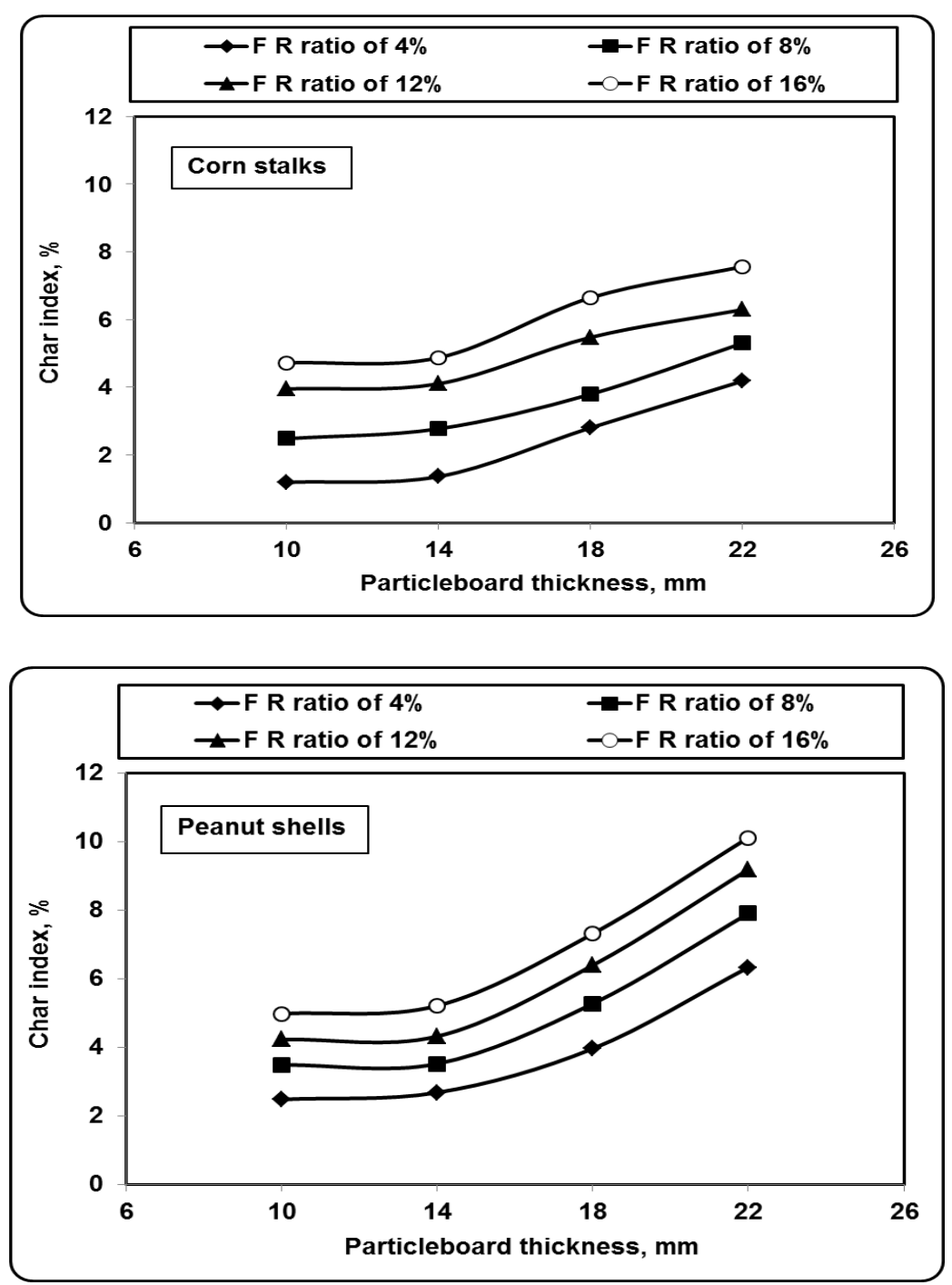

Fig. (4): Effect of sample thickness and fire retardant percentage on char index under different kinds of agricultural wastes

By looking for the effect of fire retardant percentage on the char index, the obtained data show that increasing fire retardant percentage from 4 to $16 \%$, causes an increase in the char index from 1.19 to 4.72 , from 1.36 to 4.87 , from 2.8 to 6.64 , and from 4.18 to $7.56 \%$ for corn stalks and from 2.48 to 4.98 , from 2.68 to 5.21 , from 3.96 to 7.31 , and from 6.33 to $10.11 \%$ for peanut shells at particleboard thicknesses of 10,14, 18 and $22 \mathrm{~mm}$, respectively. 
The increase of char index by increasing fire retardant percentage is attributed to that fire retardant treatment of particleboard can firstly delay the ignition for a meaningful time and secondly lower the heat release rate after ignition, resulting in an increase in both length and width of carbonization before ignition.

\subsection{Charring rate}

The influence of the char layer thickness on the wood charring rate on the basis of the time dependence of the char layer depth and the charring rate is illustrated in Fig. 5.

Concerning the effect of particleboard thickness on charring rate, obtained results show that the thickness of char layer has a significant influence on the wood charring. It was observed that increasing particleboard thickness from 10 to $22 \mathrm{~mm}$ is accompanied with a decrease in charring rate from 1.97 to 0.84 , from 1.82 to 0.71 , from 1.66 to 0.69 and from 1.6 to $0.66 \mathrm{~mm} / \mathrm{h}$ for corn stalks and from 3.84 to 1.5 , from 3.57 to 1.33 , from 3.09 to 1.17 and from 2.84 to $1.04 \mathrm{~mm} / \mathrm{h}$ for peanut shells at fire retardant percentages of $4,8,12$ and $16 \%$, respectively, as reported by Harada (1996) who clarified that the charring rate decreased when a specimen's thickness increased. The charring rate decreased by increasing particleboard sample thickness because of the high increase in the time to ignition comparing with the increase in charring depth which means that charring rate is considerably slower with a thick char layer than a thin one.

It is also noticed in Fig. 5 that increasing fire retardant percentage from 4 to $16 \%$ measured at different particleboard thicknesses of $10,14,18$ and $22 \%$, decreased charring rate from 1.97 to 1.6 , from 1.3 to 1.01 , from 0.86 to 0.69 and from 0.84 to $0.66 \mathrm{~mm} / \mathrm{h}$ for corn stalks and from 3.84 to 2.84 , from 2.52 to 1.99 , from 1.53 to 1.13 and from 1.5 to $1.04 \mathrm{~mm} / \mathrm{h}$ for peanut shells, respectively.

From the previous results, it is conducted the highly effect of the percentage of fire retardant, where it helps to minimize the charring rate of the tested particleboards as their percentage increased, therefore the smallest charring rate was obtained with particleboards containing $16 \%$ fire retardant which means that the flame spread speed decreased with increased fire retardant content in the particleboards. 

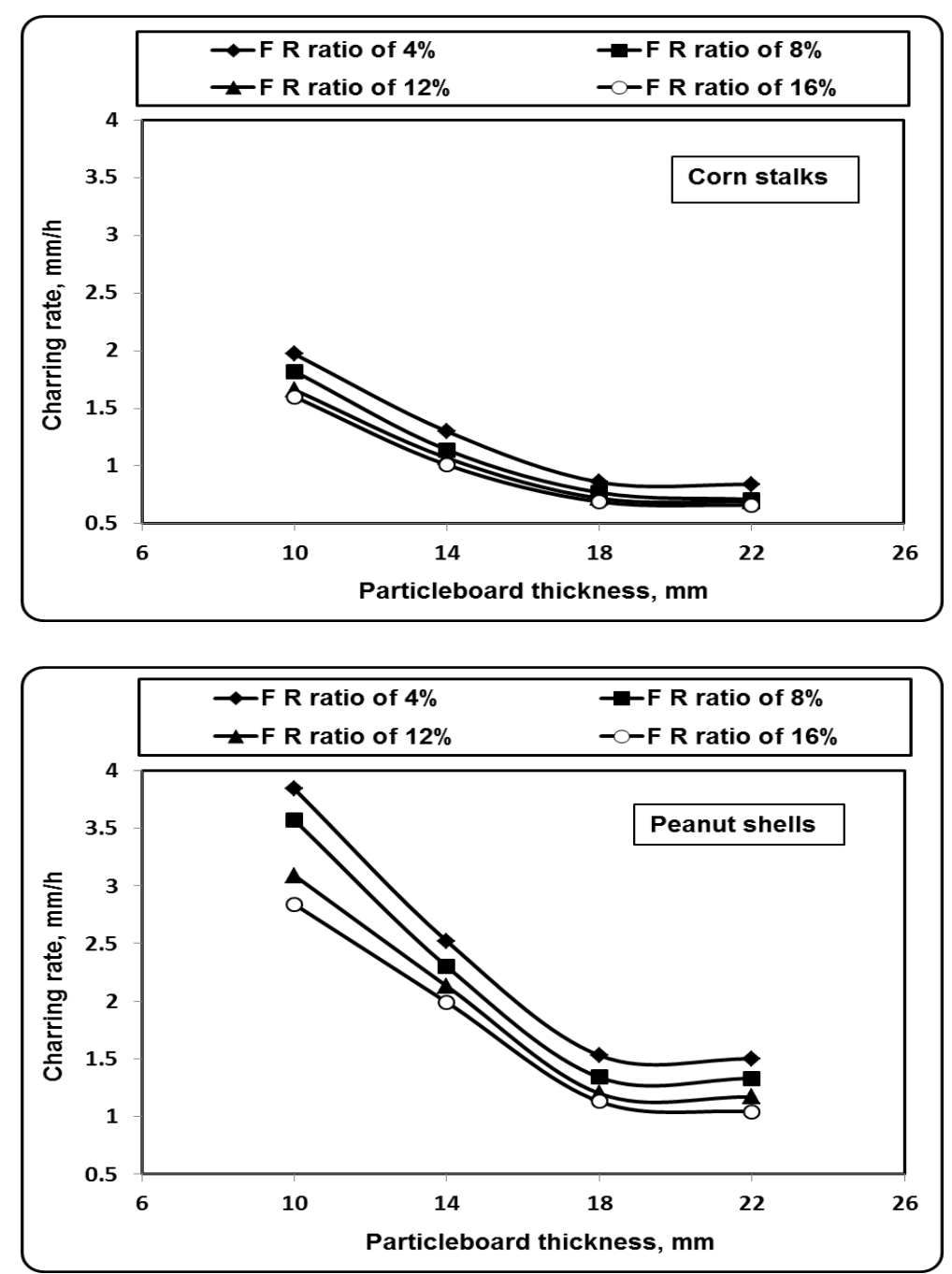

Fig. (5): Effect of sample thickness and fire retardant percentage on charring rate under different kinds of agricultural wastes

\section{CONCLUSION}

The present research was carried out to explore the possibility of applying flame retardant as a fireproofing agent, which is usually used to improve behavior of wood against fire for the production of fire retardant particleboards from agricultural wastes. From the obtained data, it can be concluded that particleboard thickness as well as fire retardant percentage are considered very important variables affecting the manufactured fire retardant particleboards performance. In addition, increasing the 
percentage of fire retardant in the particleboard manufacturing improves the properties of fire retardant.

The achieved experimental results under conditions of $16 \%$ fire retardant percentage with acceptable particleboard thickness of $22 \mathrm{~mm}$ were as follow:

- Case of fire retardant particleboard produced from Corn stalks: (245 $\mathrm{min}$ ) time to ignition, $(2.68 \mathrm{~mm})$ charring depth, $(7.56 \%)$ char index and $(0.66 \mathrm{~mm} / \mathrm{h})$ charring rate.

- Case of fire retardant particleboard produced from Peanut shells: (220 min) time to ignition, $(3.80 \mathrm{~mm})$ charring depth, $(10.11 \%)$ char index and $(1.04 \mathrm{~mm} / \mathrm{h})$ charring rate.

\section{REFERENCES}

Ayrilmis, N., Z. Candan, and R. White (2007). Physical mechanical and fire properties of oriented strandboard with fire retardant treated veneers. Holz Roh - Werkst 65: 449-458.

Basson, G. R., and W.E. Conradie (2001). Preservative and fire-retardant composition and combination and process. United States Patent \# 6319431.

Canadian Wood Council (2014). 400-99 Bank Street, Ottawa K1P 6B9 September 2014.

Garay, R. M. (2012). Lab testing for p3 moisture resistant particleboards made from wood residues. BioResources 7 (3): 3093-3103.

Güler, C., and Ü. Büyüksarı (2011). Effect of production parameters on the physical and mechanical properties of particleboards made from peanut (Arachis hypogaea L.) hull. BioResources 6 (4): 5027-5036.

Güler, C., I.S. Halil, and Y. Sevcan (2016). The potential for using corn stalks as a raw material for production particleboard with industrial wood chips. Wood Research 61 (2): 299-306.

Harada, T. (1996). Charring of wood with thermal radiation: II. Charring rate calculated from mass loss rate. Mokuzai Gakkaishi 42: 194-201. 
Harada, T., U. Saburou, and M. Hideaki (2006). Fire resistance of thick wood-based boards. Journal of Wood Science 52: 544-551.

Hume, J. (1992). Assessing the fire performance characteristics of GRP composites. In: International conference on materials and design against fire. London, pp.: 11-15.

Karastergiou, P.S., and J.L. Philippou (2000). Thermogravimetric analysis of fire retardant treated particleboards. Wood and Fire Safety: 385-394.

Khozeini, A., T. Tabarsa, and M. Mashkour (2014). A novel method for manufacturing of wood flour/PP composites with better fire retardancy and mechanical properties. International Journal of Lignocellulosic Products 1 (2): 121-133.

Mikkola, E. (1991). Charring of wood based materials. Proceedings of the third international symposium on fire safety science (Edinburgh), Elsevier Science Publishers: Oxford: 547-556.

Mouritz, A.P., and A.G. Gibson (2006). Fire properties of polymer composite material. Springer, Berlin, pp.: 59-101, Chap 3.

National Building Code of Canada (2010). National Research Council, Ottawa.

Okai, R., O.A. Emmanuel, J.M. Stephen, and K.D. Raphael (2015). Production of Wood Products from Particleboards Manufactured from Agricultural Residues. International Journal of Emerging Technology and Advanced Engineering 5 (9): 30- 38.

Pedieu, R., K. Ahmed, R. Bernard, W. Xia-Ming, and D. James (2012). Fire-retardant properties of wood particleboards treated with boric acid. European Journal of Wood and Wood Products 70: 191-197.

Reham, S. A. (2017). Recycling of agricultural residues for producing high quality pressed wood. Ph.D. Thesis, Faculty of Agriculture, Zagazig University, Egypt. 
Rowell, R.M., and S.L. LeVan-Green (2005). Thermal properties in: Rowell RM (ed) Handbook of wood chemistry and wood composites. Boca Raton, London, New York, Washington, DC, pp.: 121-138, Chap 6.

\section{الملخص العـربـى \\ تأثثير مثبط الحريق على أداء الإحتراق للأخشاب المضغوطة

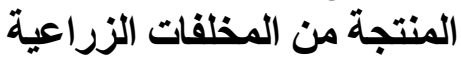 \\ د. هند أحمد مجدى المغاوري}

تعتبـر العمليـات الصـناعية المسـتخدمة حاليـاً لصـناعة الأخثــاب مـن الأسـاليب المتقدمـة تكنولوجيًا

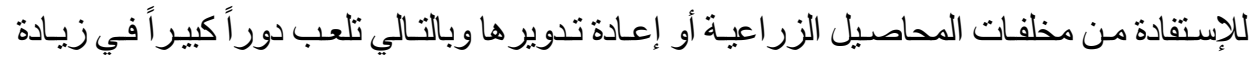

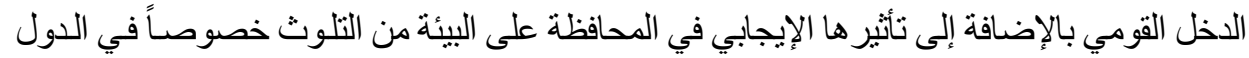

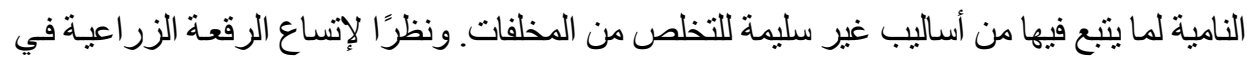

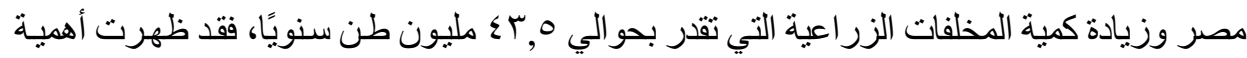
الإستفادة من كميات المخلفات الناتجة في زيادة قيمة العائد الاقتصادي و البيائي.

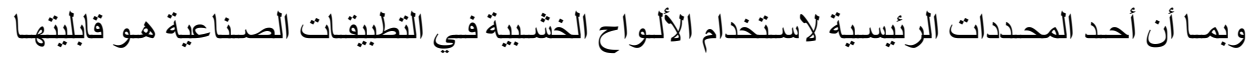

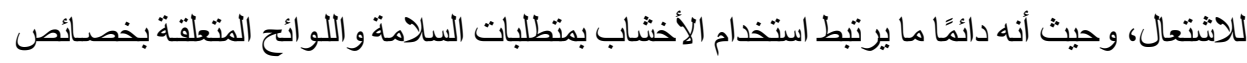

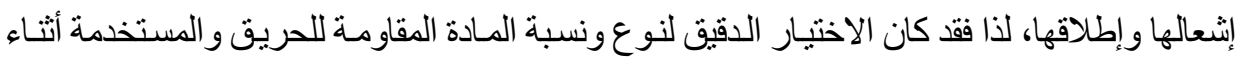
عملية تصنيع الألواح الخثبية (الحبيية) أثر كبير في التغلب على هذه الظاهرة.

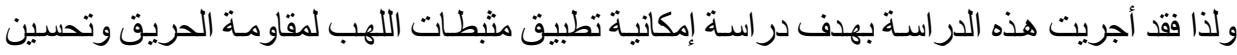
سلوك الخشب ضد الحريق ودر اسة تأثير ها على أداء الحرائق أثناء عملية إنتاج ألواح الخشب الثبن الحبييية

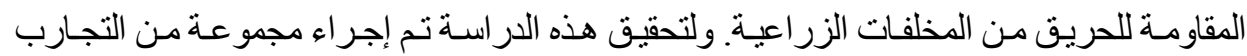

لاختبار ألواح الخشب المصنعة تحت عو امل نشغيل مختلفة: نوعان مختلفان من المخلفات الزر اعية (حطب الذرة ـ قشور الفول السوداني).

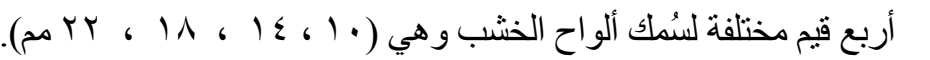

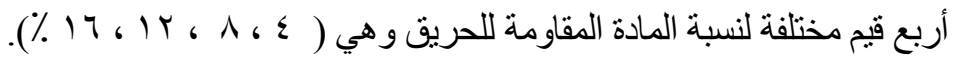

وقد تم تقييم المعاملات السابقة أخذاً في الاعتبار كلاً من وقت الإشتعال، عمق الحرق، نسبة الحرق،

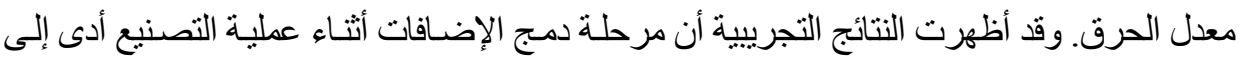

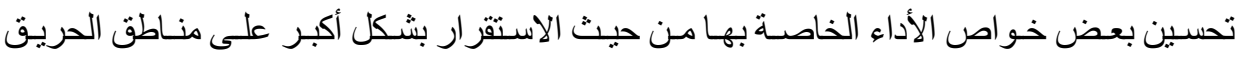
وبالتالي زيادة مقاومة الألواح المصنعة للحريق.

مدرس بقسم الهندسة الزراعية - كلية الزراعة - جامعة الزقازيق 


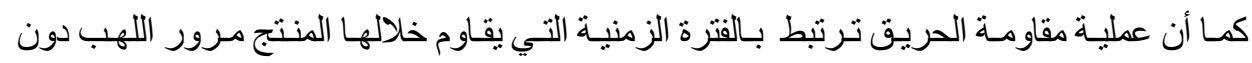

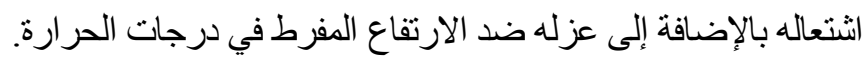

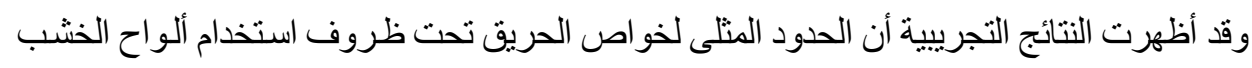

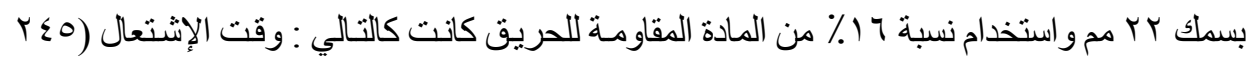

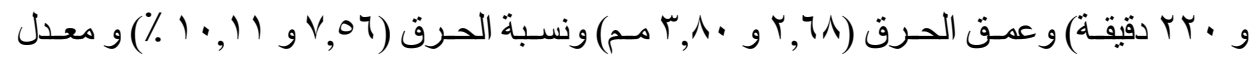

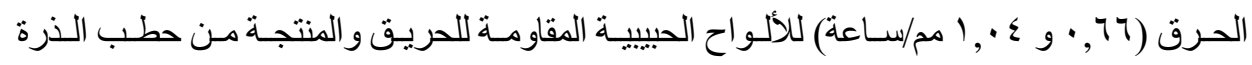
وقثور الفول السوداني على الترتيب. 